\title{
Asian Seismological Commission - A Bright History and Challenges Ahead
}

\author{
R. K. Chadha \\ Former Secretary General - ASC \\ Present Address: CSIR-National Geophysical Research Institute, Uppal Road, Hyderabad - 500 007, India \\ E-mail: rajen0555@gmail.com
}

\begin{abstract}
The Asian Seismological Commission (ASC) completed 25 years in August 2021 after fulfilling its primary aim of bringing together, Earth scientists from Asia and Oceania regions. Since its first formal meeting in Tangshan, China during August 1-3, 1996 under the umbrella of IASPEI Regional Assembly, ASC independently organized 11 General Assemblies across the Asian Continent from Armenia and Iran in western Asia to Australia in Oceania, once every two years, without a break. The Training Courses in Seismology preceding these Assemblies greatly helped in developing a strong work force that came very handy after the extreme event of 2004 Indian Ocean tsunami and underlined the importance of scientific cooperation within Asian and Pacific Ocean countries. The Global Seismic Hazard Assessment Program (GSHAP) in its closing report to the IDNDR/ STC (1992-98) acknowledged the significant contributions of the first two ASC technical meetings held in Beijing $(10 / 93,10 / 94)$ and Hyderabad, India (3/96) in the outcome of their program in Eastern Asia (GHSAP Region 8). This paper describes the ASC events that occurred during its journey from birth to reaching the pinnacle of its glory at the end of the Silver Jubilee Year in 2021. This paper will also serve as a recorded history for posterity to build upon the efforts already made, by the coming generations in this field.
\end{abstract}

\section{INTRODUCTION}

When we look at the history of natural hazards, globally, earthquakes and tsunami stand out as the major culprits, which took human lives and enforced economic losses in the world. The situation in Asia, the locale of most of the developing countries is highly vulnerable to these hazards because of the global tectonics. Asia, with her vast territory and large population, has the most intense seismicity and earthquake disasters in the world. The question is "while the phenomena are global and natural, why people in the developing countries in Asia suffer more than the people in the developed countries?" The simple answer is lack of awareness, resource crunch, non-availability of trained manpower and technological development to counter these natural hazards in Asian and some other third world countries like Haiti in the Caribbean and South America.

Since, countries in Asia cannot alter the vulnerability to earthquakes and tsunami a mechanism needs to be developed to counter these hazards. A lot of work has been done in earthquake hazard evaluation and mitigation to alleviate the sufferings of the people in recent times, in the absence of a workable prediction model, which is still a distant goal. These advancements in knowledge need to be percolated through concerted efforts at a regional and global level through interactions with peers in the technologically developed world.

ASC was born to address such issues after devastating earthquakes occurred in China, India, Iran, Indonesia, Japan and Philippines in the later half of the $20^{\text {th }}$ century at an alarming frequency. China and India took the lead and made enormous efforts to provide a platform where exchange of ideas within the Asian and Oceana countries can cross-pollinate for the mutual benefit of people. For the success of any major scientific endeavor a few minds and several hands are required. To put on record Prof. Harsh Gupta from India and Prof. Zhu Chaunzhen from China were the architects behind the formation of the Asian Seismological Commission. This report is an attempt to provide details of events that took place under the aegis of ASC till its Silver Jubilee Year in 2021.

\section{BIRTH OF ASIAN SEISMOLOGICAL COMMISSION}

The idea of the formation of ASC as one of the Regional Commissions of IASPEI was supported by Dr. Eric Robert Engdahl, the then Secretary General who offered both academic and financial backing during the preparatory meeting in 1995 in China, where India participated along with other Asian countries like Iran, Japan, Korea, The Philippines and Vietnam. This was followed by the announcement of the establishment of ASC during the IASPEI Regional Assembly in Tangshan, China in August 1996. This was considered as the First General Assembly of the ASC where representatives of 19 countries that include Australia, Azerbaijan, Bangladesh, China, India, Iran, Israel, Japan, Kazakhstan, Korea, Kyrgyzstan, Nepal, New Zealand, Pakistan, Russia, Thailand, The Philippines, Turkey, and Vietnam were present to endorse the formation of ASC. Prof. Harsh Gupta, India and Prof. Zhu Chaunzhen, China were elected as the founding President and Secretary General of the ASC along with two Vice Presidents, Prof. H. Hamada from Japan and Dr. Gary Gibson from Australia. A virtual office of the Secretariat was established with Secretary General in China, which later moved with the location of respective Secretary Generals in the following years.

\section{ASC GENERAL ASSEMBLIES}

\section{Hyderabad, India (1998)}

The Second General Assembly of ASC laid the foundation of achieving its objectives by organizing the First full-fledged Conference on "Earthquake Hazard Assessment and Earth's Interior related topics" and an International Training Course on Seismology. The CSIR:National Geophysical Research Institute (NGRI), Hyderabad, India organized and hosted this Assembly during 1-3 December 1998. It attracted 189 abstracts and 200 delegates attended the Assembly with 70 participants from outside India representing 26 countries. Eight technical sessions addressing several issues from earthquake prediction and hazard to physics of earthquake processes and induced seismicity were held. A very interesting session on "Current trends in dissemination of seismological and other geophysical information and educating the public on seismic disaster mitigation" underlined the significance of public education, regional seismic information systems, 
observatory practices and training programs. A workshop on GARNET (Global Alliance of Regional Networks) Program was held to enthuse the participating countries to become a part of the global networking by linking regional networks to study deep Earth's structure by exchanging waveform data for certain specific and large earthquakes.

A 15-Day International Training Course on "Seismic Monitoring, Data Analysis and Exchange" preceded the General Assembly during November 15-30 1998. 25 trainees were selected from 70 applications received by the Organizing Committee. The break-up is as follows: India (8), China (6), Iran (3), Oman (2) and one each from Uzbekistan, Kyrgyzstan, Georgia, Zambia, Yemen and Indonesia. The faculty was drawn from NGRI, GeoForschungs Zentrum (GFZ), Potsdam, Germany, University of Bergen, Norway, Kinematrics SA, Switzerland and India Meteorological Department, New Delhi. The topics covered were the basics of seismology and seismometry, data acquisition, observatory practices, data analysis and earthquake mechanisms. A daylong visit to the epicentral area of the devastating 1993 Latur earthquake was arranged for the participants to acquaint them with the field observations of an earthquake-affected area.

Both, the General Assembly and Training Course were supported by NGRI (Council of Scientific and Industrial Research), Indian National Science Academy, Department of Science and Technology, Government of India, UNESCO, IDNDR, COSTED, IASPEI and GFZ, Germany.

\section{Tehran, Iran (2000)}

The third General Assembly was held at the Institute of Geophysics, Tehran University, Iran during 10-12 October 2000. 270 abstracts were received and 160 delegates representing 23 countries attended the Assembly. Several technical sessions focused on a wide spectrum of research related to Seismology and the Earth's Interior. The symposium was followed by two technical workshops on "Educating the Public about Earthquake Hazard and risk" and "Seismic Networks and Site Selection". A Post-Symposium field trip to East-Central Iran was organized where eight major earthquakes had occurred in the last three decades.

A pre-symposium International Regional Training course on "Seismology and Mitigation of Seismic Disasters" was conducted by the LOC. The new methods to determine the source parameters were discussed and were followed by practical training on computers. New understanding of seismotectonics, earthquake prediction and inversion methods was included in the course. 25 trainees from 6 countries attended the course. The IASPEI, Ministry of Culture and Higher Education, Iran and the Committee for Reduction of Natural disasters in Iran supported the Assembly, training course and the field visit.

\section{Kathmandu, Nepal (2002)}

The fourth General Assembly was held in Kathmandu, Nepal during 24-26 November 2002 in the backdrop of the assassination of the members of Royal Family of Nepal. But still 200 delegates from 22 countries attended the Assembly that received 110 abstracts. A Symposium was organized on "Seismology, Earthquake Hazard Assessment and Risk Management" in conjunction with National Society for Earthquake Technology (NSET), Nepal and Asian Disaster Preparedness Centre (ADPC). In this Assembly an effort was made to expand the scope of the Symposium to include earthquake engineering and earthquake risk management. As such a training program on Earthquake Vulnerability Reduction for Cities (EVRC) was organized for about 30 participants.

IASPEI, HMG/Ministry of Science and Technology (MOST), Nepal and B. P. Koirala India-Nepal Foundation provided funds for hosting the Symposium and The International Institute for
GeoInformation Science and Earth Observation (ITC), the Netherlands extended full cooperation in organizing the training program.

\section{Yerevan, Armenia (2004)}

The Armenian Association of Seismology and Earth Physics organized the fifth General Assembly in Yerevan, Armenia during 1821 October 2004. A Symposium on "Seismic Hazard Evaluation and Risk Reduction" with 8 technical sessions was held in which 275 delegates from 51 countries including 26 from Europe and Americas participated. This Assembly was dedicated to the 15th anniversary of the devastating Spitak earthquake in Armenia in December 1988. The Prime Minister of Armenia received the delegation of the participants and appreciated the efforts of ASC to bring the world's scientific community to a common platform to address the problems affecting the people in Asian countries.

A 15-Day Pre-Symposium International Training Course on "Recent Trends in Seismic Networks Data Processing \& Exchange, Hazard and Risk Assessment" was held to develop a strong work force of seismologists in Asian countries. The Symposium was followed by a field trip to the epicentral area of the Spitak earthquake.

It was unfortunate that Serguei Yu. Balassanian, the President of the ASC died in a tragic road accident on November 23, 2004, one month after the fifth General Assembly.

\section{Bangkok, Thailand (2006)}

The sixth General Assembly was held during 7-9 November 2006 in Bangkok against the backdrop of the unexpected coup in Thailand. But, with the commitment and undaunted efforts of the Thai Meteorological Department (TMD), National Earthquake Committee of Thailand (NECT), Engineering Institute of Thailand (EIT) and the Asian Disaster Preparedness Center (ADPC) the Assembly went on smoothly (Figure 1). It was a grand success where more than 150 delegates participated from 20 countries in Asia. The efforts of sponsorship from IUGG, IASPEI and UNESCO are truly laudable and show their commitment towards international cooperation and inclusiveness.

This Assembly was the first opportunity for the ASC to address the Tsunami hazard in Asia after the M9.3 earthquake in Sumatra and the ensuing tsunami in the Indian Ocean in December 2004, which claimed more than 300,000 human lives. There was another devastating earthquake prior to this Assembly; the Kashmir earthquake in 2005, which claimed more than 80,000, lives in Pakistan. A special session on "Subduction zone, seismology and tsunami"

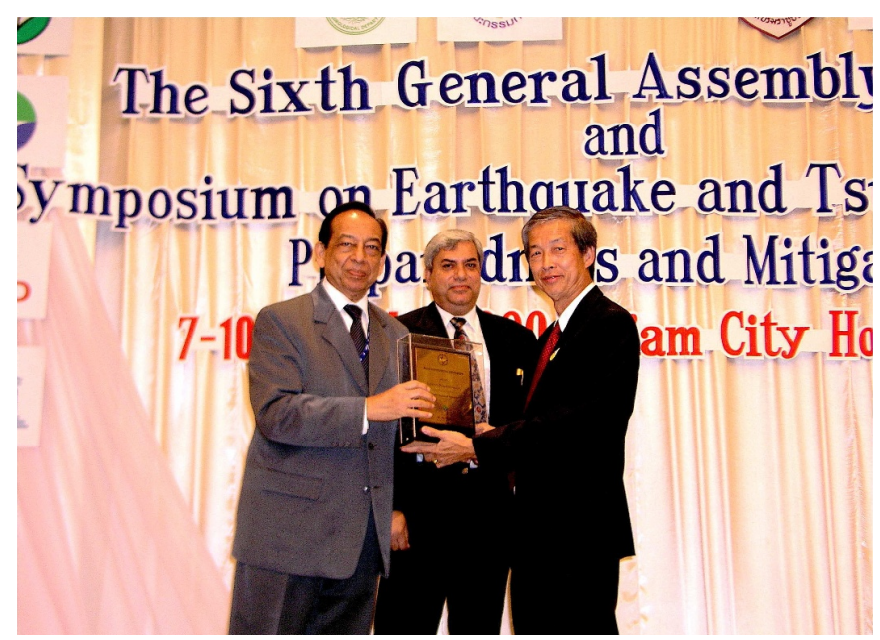

Fig.1. Prof. Harsh Gupta (left), Founder President of ASC presenting a memento to Mr. Suparerk Tansriratanawong (extreme right), President LOC of the $6^{\text {th }}$ General Assembly in Bangkok in 2006. Dr. R K Chadha, Secretary General is in the center. 
was added to the planned 5 technical sessions to invite reports, data and observations and research on this very important topic. A total of 27 oral presentations were made in this Session. These presentations included 6 invited talks and addressed three major issues on Tsunami in general, Sumatra earthquake of December 26, 2004 and tsunami, in particular and seismicity and structure along plate boundaries. Presentations on tsunami included details of field surveys in China, Vietnam, Iran, Thailand, Yemen, Srilanka and India. The ASC and ADPC also organized the pre-assembly training course on seismology.

\section{Tsukuba, Japan (2008)}

The seventh General Assembly in Japan closely followed the Wenchuan earthquake in China in 2008. The Assembly was held in Tsukuba, Japan during 24-28 November 2008 along with the Fall Meeting of the Seismological Society of Japan (SSJ). The main theme of the Assembly was "Sharing of Up-to-date Science and Technology to Reduce Earthquake Disaster in Asia". It was aimed at bridging science and technology faculties, research and application, domestic efforts and international collaboration to Asia-Pacific region and the whole world. The goal was capacity building in Asia-Pacific for the reduction of earthquake disasters.

More than 800 participants from 39 countries attended this joint ASC-SSJ Assembly. There was a special session dedicated to the Wenchuan earthquake of 2008 in China. The Disaster Prevention Research Institute (DPRI) of Kyoto University organized a preAssembly training course on seismology during 18-21 November 2008. A short 2-Day training course on "Microtremor Array Exploration Technique" was also held during 23-24 November by the cooperation of SSJ, the International Institute of Seismology and Earthquake Engineering (IISEE) and the Building Research Institute, Japan. The SSJ provided full financial support for travel, stay and registration to all the trainees. 13 participants from Armenia, Bhutan, Egypt, Georgia, India, Indonesia, Kazakhstan, Myanmar, Nepal, Palestine Uzbekistan and Yemen were trained in Spatial Autocorrelation Methods that are very popular in Earthquake Engineering for Microzonation and site specific studies.

\section{Hanoi, Vietnam (2010)}

The $8^{\text {th }}$ General Assembly was held in Hanoi, Vietnam during 810 November 2010 with a Symposium on "Mitigating seismic hazard and disasters in Asia". 287 participants, from 32 countries viz., Algeria, Armenia, Australia, United Kingdom, China, Philippine, Georgia, France, India, Indonesia, Iran, Israel, Italy, Japan, Jordan, Kazakhstan, Mongolia, Morocco, Myanmar, New Zealand, Pakistan, Palestine, Romany, Russia, Saudi Arabia, Slovenia, South Korea, Thailand, Taiwan, Ukraine, USA, and Vietnam attended the Assembly. 70 Participants received full or partial grants from LOC.

A Pre-Assembly Training Course on "Seismic Hazard and disasters in Asia" was conducted during 5-7 November 2010 in which 20 participants were trained. A post-Assembly field visit to Red River Fault Zone was arranged during 11-13, 2010 to show "Evidences of neotectonic activities related to possible earthquakes along the seismically active Red River Fault zone (Vietnamese Segment) during Late Tertiary-Quaternary period".

\section{Ulanbaatar, Mongolia (2012)}

The 9th General Assembly was held in Ulaanbaatar, Mongolia during 17-20 September 2012 and was inaugurated by the Deputy Prime Minister of Mongolia Mr. D.Terbishdagva. The Assembly was organized by the Permanent Council on Seismic Risk Mitigation of the Government of Mongolia, National Emergency Management Agency (NEMA), Mongolian Academy of Sciences (MAS), Research Center of Astronomy and Geophysics (RCAG) of Mongolian Academy of Sciences and also co-sponsored by International Union of Geodesy and Geophysics (IUGG) and International Association of Seismology and Physics of the Earth's Interior (IASPEI).

About 300 scientists including 115 foreign participants from 20 countries participated in the conference and made 87 oral and 50 poster presentations. The Mongolian Government provided the excellent premises with the opening ceremony held in the Mongolian Parliament. A field visit was arranged for all the participants to witness the seismically active strike-slip faults in the region.

\section{Manila, Philippines (2014)}

The Philippine Institute of Volcanology and Seismology (PHIVOLCS-DOST) along with Geological Society of the Philippines (GSP), International Association of Physics of the Earth's Interior (IASPEI), Seismological Society of Japan (SSJ) organized the $10^{\text {th }}$ General Assembly in the Makati City, Manila during 17-20 November 2014. The theme of the Symposium was "Working together towards an earthquake-resilient Asia". The technical sessions covered the following topics: seismological observation and interpretation, nature of seismic sources and prediction of earthquakes, strong ground motion, instrumentation, seismic network and volcano seismology; earthquake hazards and risks mapping and assessment, earth structure and geodynamics; seismotectonics; physics and chemistry of materials, earthquake engineering, and education, outreach and communication in seismology and disaster risk reduction.

232 delegates from 22 countries participated in the Assembly where 89 oral and 44 poster presentations were made. A Pre-Assembly training course was organized from 12 to16 November 2014 at Sequoia Hotel, Quezon City, which was attended by 21 participants from 6 countries. A large number of presentations were also made by the young scientists of PHIVOLCS on seismic hazards and volcanic studies in Philippines that gave a better understanding of the natural hazards in the country. Post-Assembly field trips were organized to Bohol province and Taal Volcano.

\section{Melbourne, Australia (2016)}

The eleventh General Assembly was held in Melbourne, Australia during 25-27 November 2016. The Assembly was jointly organized by ASC and the Australian Earthquake Engineering Society (AEES) and highlighted the interdisciplinary exchange of earthquake and engineering seismology. About 90 participants from Australia, China, India, Russia, Japan, Indonesia, and New Zealand attended the meeting, with 103 abstracts submitted.

\section{Chengdu, China (2018)}

The $12^{\text {th }}$ General Assembly was held along with International Conference for the "Decade Memory of the Wenchuan earthquake in China in 2008" during 12-14 May 2018 and the $4^{\text {th }}$ International Conference on Continental Earthquakes ( $4^{\text {th }}$ ICCE).

A Pre-Assembly training course was organized on seismological observations, mainly focusing to central Asian countries where a Chinese project of joint seismograph network was in progress. A special issue was brought out based on 58 submissions out of which 34 were accepted for peer review, a few of them being the presentation during the $12^{\text {th }}$ ASC conference.

\section{Sharm Elsheikh, Egypt (2020)}

The $13^{\text {th }}$ General Assembly was planned in Sharm Elsheikh, Egypt during June 1-3, 2020. The planned Assembly could not be held due to Covid-19 pandemic that affected the entire world. The ASC bureau is in constant touch with the organizers but uncertainty prevails. Till the time of writing this manuscript discussions were held to look for alternate modes for conducting the Assembly. 


\section{ASC BUREAU MEMBERS}

The ASC Bureau is elected once in four years. Considering a low attendance of the delegates and lack of quorum in the $11^{\text {th }}$ General Assembly in Melbourne, Australia the elections were postponed to IASPEI Regional Assembly in Kobe, Japan during 2017. In the Business Meeting of ASC in Kobe, Japan a new Bureau was elected. Table 1 shows the list of ASC Bureau since its formation in 1996.

Table 1. Asian Seismological Commission Bureau Members since its formation in 1996. Elections could not be held during 2016 ASC in Australia. The new Bureau was elected during IASPEI Regional Assembly in Kobe, Japan in 2017.

\begin{tabular}{|c|c|c|}
\hline Position & Name & Years \\
\hline President & $\begin{array}{l}\text { Harsh Gupta (India) } \\
\text { Serguei Yu. Balassanian (Armenia) } \\
\text { Zhu Chaunzhen (China) } \\
\text { Kazuro Hirara (Japan) } \\
\text { Gary Gibson (Australia) } \\
\text { Parmesh Banerjee (Singapore) }\end{array}$ & $\begin{array}{l}1996-2000 \\
2000-2004 \\
2004-2008 \\
2008-2012 \\
2012-2017 \\
2017-\text { Present }\end{array}$ \\
\hline $\begin{array}{l}\text { Vice } \\
\text { Presidents }\end{array}$ & $\begin{array}{l}\text { H. Hamada (Japan) } \\
\text { Gary Gibson (Australia) } \\
\text { D. Rhoades (New Zealand) } \\
\text { M.Gheitanchi (Iran) } \\
\text { S.Goldin (Russia) } \\
\text { Cao Din Trieu (Vietnam) } \\
\text { Cao Din Trieu (Vietnam) } \\
\text { Prachaub Sumallee (Thailand) } \\
\text { Chen Yun Tai (China) } \\
\text { Bartolome C. Bautista (Philippines) } \\
\text { Ruben Tatevossian (Russia) } \\
\text { Toshiaki Yokoi (Japan) }\end{array}$ & $\begin{array}{l}1996-2000 \\
1996-2000 \\
2000-2004 \\
2000-2004 \\
2004-2008 \\
2004-2008 \\
2008-2012 \\
2008-2012 \\
2012-2017 \\
2012-2017 \\
2017-\text { Present } \\
\text { 2017-Present }\end{array}$ \\
\hline $\begin{array}{l}\text { Secretary } \\
\text { General }\end{array}$ & $\begin{array}{l}\text { Zhu Chaunzhen (China) } \\
\text { Zhu Chaunzhen (China) } \\
\text { Rajender Chadha (India) } \\
\text { Rajender Chadha (India) } \\
\text { Rajender Chadha (India) } \\
\text { Li Li (China) }\end{array}$ & $\begin{array}{l}1996-2000 \\
2000-2004 \\
2004-2008 \\
2008-2012 \\
2012-2017 \\
2017-\text { Present }\end{array}$ \\
\hline Members & $\begin{array}{l}\text { Kazuro Hirahara (Japan) } \\
\text { Ding Zhifeng (China) } \\
\text { Alexander Ponamerev (Russia) } \\
\text { Toshiaki Yokoi (Japan) } \\
\text { S. Demberal (Mongolia) } \\
\text { D. Srinagesh (India) } \\
\text { Esline Galaebiti (Vanuatu) } \\
\text { Gary Gibson (Australia) }\end{array}$ & $\begin{array}{l}\text { 2004-2008 } \\
2008-2012 \\
2012-2017 \\
2012-2017 \\
\text { 2012-2017 } \\
\text { 2017-Present } \\
\text { 2017-Present } \\
\text { 2017-Present }\end{array}$ \\
\hline
\end{tabular}

\section{SUMMARY AND CONCLUDING REMARKS}

The vision to bring seismologists and Earth scientists together from Asia and Oceania regions and forge an alliance to develop a strong work force to face the challenges of earthquake and tsunami disasters bore fruits during the first 25 years of ASC. The 12 General Assemblies held till 2018 were fairly spread over the Asian continent with extended outreach till Australia (Figure 2).

More than 2500 scientists interacted with each other during these meetings and discussed their local problems in their respective countries with regard to natural hazards, specifically the earthquakes and tsunami. The presence of peers from Asia, Europe and America further added to the quality of interactions during the Assembly and greatly helped in training courses on seismology, which preceded each of these meetings. On an average, every Assembly had a participation

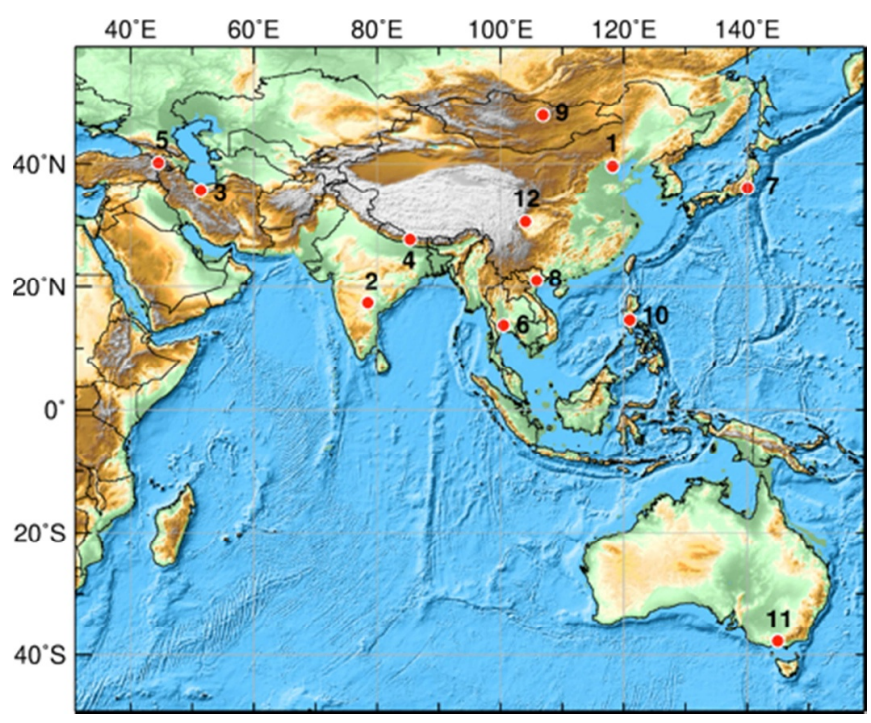

Fig.2. Locations of ASC General Assemblies in Asia and Oceania regions; 1=Tangshan, China (1996), 2=Hyderabad, India (1998), 3=Tehran, Iran (2000), 4=Kathmandu, Nepal (2002), 5=Yerevan, Armenia (2004), 6=Bangkok, Thailand (2006), 7=Tsukuba, Japan (2008), 8=Hanoi, Vietnam (2010), 9=Ulanbaatar, Mongolia (2012), 10=Manila, Philippines (2014), 11=Melbourne, Australia (2016) and $12=$ Chengdu, China (2018). Unique tectonic setting in each country is obvious and presents a new challenge for mitigation of earthquake and tsunami hazard.

of 200-250 delegates from at least 25 countries, including the host. This greatly helped in the multiplication of trained manpower in most of the developing countries in Asia, which came very handy whenever any earthquake disaster struck their country; especially the M9.3 Sumatra earthquake and the Indian Ocean tsunami that affected several countries, is one such example.

ASC in its Silver Jubilee Year is at its prime youth and has successfully achieved its envisioned goals and objectives for which it was formed. The unstinted support of its founding President and Secretary General, ably assisted by all the other Bureau members, so far, have demonstrated that even with minimal financial support ASC was able to hold its Biennial Assemblies without any break. This was possible because of the strong desire and commitment of the host countries that provided most of the funds to organize these Assemblies and the training courses.

It becomes very important now to nurture ASC into its next phase of maturity, which needs the continuous support of the member countries in terms of finance and expertise of men and material. In this journey the role of international bodies is of utmost importance for the survival and flowering of ASC into a healthy and vibrant organization to serve the mankind.

It is a common knowledge that Asia and Pacific regions are more prone to earthquake and tsunami hazards due to global geodynamics. The last 120 years of global earthquake data had shown that, while there is no appreciable change in the decadal average frequency of damaging earthquakes of M6.0, the loss of human lives related to this phenomenon has increased considerably in the recent times due to some extreme events. Although, earthquakes and tsunami are global events, it took more than half-a-million human lives in Asia-Pacific countries during the first two decades of $21^{\text {st }}$ century. Some of the most damaging ones occurred in China, Haiti, India, Iran and Japan and caused economic losses exceeding billions of US dollars. Two extreme events that are still in the fresh memory of people are the Indian Ocean Tsunami in 2004 due to M9.3 Sumatra earthquake and M9.0 Tohoku earthquake and Tsunami in Japan in 
2011. We realize that extreme events have occurred in the past and will continue to occur in future. There is a need to plan and cooperate to manage these natural hazards so that we can learn to live safely with them.

In today's highly globalized economy, when a disaster occurs it creates unpredictable turmoil not just in the affected area but also has its impact all over the world. Counter-measures against these largescale disasters are crucial for sustainable development of the global economy to ensure human security. It is time now that international frameworks are activated and collaborations encouraged which will help gather information on disaster mitigation in the Asia-Pacific Region. These efforts are resource and funds intensive and require collective wisdom and support of executives, scientists, engineers and other stakeholders, if human losses are to be minimized. Asian Seismological Commission is all set to play a strong leadership role in this direction to counter the vagaries of nature so that we all can coexist with them.

Acknowledgements: I thank Prof. Harsh Gupta, the founder President who was primarily responsible for my election as Secretary General of the Asian Seismological Commission in Yerevan, Armenia in 2004. I served for three consecutive terms from 2004 to 2017 getting re-elected in Tsukuba, Japan and Ulanbaatar, Mongolia. I express my sincere thanks to all the office bearers of ASC, IASPEI and IUGG who were very helpful while organizing ASC Assemblies, Training Courses and Business Meetings in their Regional and General Assemblies during my tenure. The manuscript is prepared using information from my personal notes, IASPEI and other host countrys' websites and is duly acknowledged. I thank Dr. Prakash Kumar of CSIR-NGRI for helping me to prepare Figure 2 of this manuscript.

(Received: 5 October 2021; Revised form accepted: 25 October 2021) 